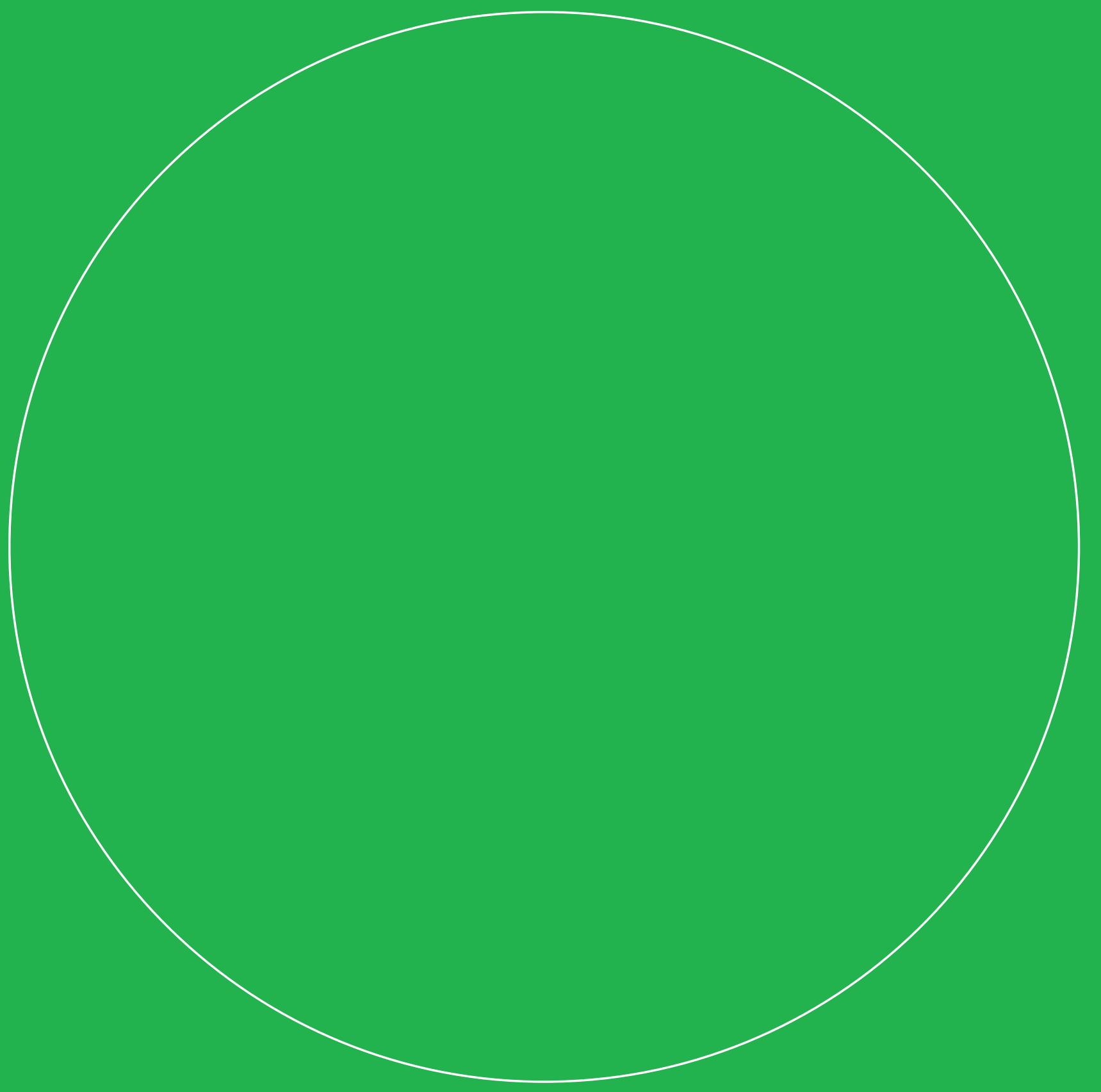

\title{
Methods to find food-health relations for personalized advice
}

dr. G. (Görkem) Simsek-Senel, MSc M.J. (Meeke) Ummels, drs. M.J. (Mariëlle) Timmer, dr. J.L. (Jan) Top

CONFIDENTIAL 



\section{Methods to find food-health relations for personalized advice}

Authors: dr. G. (Görkem) Simsek-Senel, MSc M.J. (Meeke) Ummels, drs. M.J. (Mariëlle) Timmer, dr. J.L. (Jan) Top

This research project has been carried out by Wageningen Food \& Biobased Research commissioned and funded by TKI Agri \& Food (TKI-AF-15262). The work was conducted in an objective way by researchers who act impartially with respect to the client(s) and sponsor(s). 
WFBR Project number: 6239108701

Version: Final

Reviewer: dr. H. (Hajo) Rijgersberg

Approved by: dr.ir. H. (Henk) Wensink

Funded by: TKI Agri \& Food (TKI-AF-15262)

Confidentiality of the report: Confidential until February 2021

(C) 2021 Wageningen Food \& Biobased Research, institute within the legal entity Stichting Wageningen Research.

Confidential report. The research that is documented in this report was conducted in an objective way by researchers who act impartial with respect to the client(s) and sponsor(s). Nothing from this publication may be reproduced and/or made public without prior written permission by the director of Wageningen Food \& Biobased Research. This report can be downloaded for free from February 2021 at https://doi.org/10.18174/540283/ or at www.wur.eu/wfbr (under publications).

PO box 17, 6700 AA Wageningen, The Netherlands, T + 31 (0)317 4800 84, E info.wfbr@wur.nl, www.wur.eu/wfbr.

All rights reserved. No part of this publication may be reproduced, stored in a retrieval system of any nature, or transmitted, in any form or by any means, electronic, mechanical, photocopying, recording or otherwise, without the prior permission of the publisher. The publisher does not accept any liability for inaccuracies in this report. 


\section{Contents}

$\begin{array}{ll}\text { Summary } & 4\end{array}$

1 Introduction $\quad 5$

2 Methodology: finding and assessing evidence $\quad 6$

$\begin{array}{lll}2.1 & \text { Types of studies and level of evidence } & 6\end{array}$

$\begin{array}{ll}2.2 & \text { Aspects of health }\end{array}$

2.3 Steps followed to find scientific evidence for the Dutch Dietary Guidelines $2015 \quad 9$

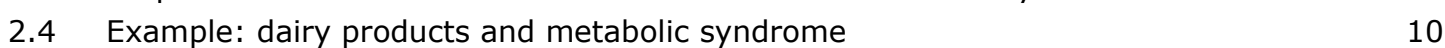

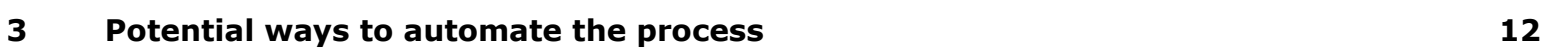

$\begin{array}{ll}3.1 & \text { Finding publications } \\ 3.2 & 12\end{array}$

$\begin{array}{ll}3.2 & \text { Automated summaries } \\ 3.3 & 13\end{array}$

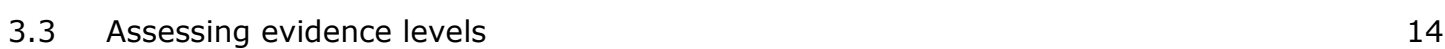

4 Conclusion $r$

$\begin{array}{ll}\text { Literature } & 17\end{array}$

APPENDIX 1 


\section{Summary}

Digital personalised dietary advice is increasingly popular. However, reference to scientific knowledge is often missing or only given indirectly. As a consequence, new insights are either neglected or taken up without adequate scientific rigour. In the Personalized Nutrition and Health (PNH) Project we aim to strengthen dietary advice for the consumer using scientific evidence. This advice is based on the 'Dutch Dietary Guidelines 2015', published by the Health Council of The Netherlands (Gezondheidsraad), extended with more recently found evidence.

The Dietary Guidelines document presents detailed food-health relations using scientific evidence from literature, including the resulting guidelines. An accompanying document describes the approach that was followed to find evidence in literature and explains a detailed methodology for assessing the evidence. The entire process of finding and assessing literature is done manually by the Health Council committee. However, the discovery of relations between food and health continues over time and the process of assessing the scientific evidence demands large use of resources. We submit that automated reasoning will make the process of finding and assessing the scientific evidence more effective and will help keeping scientific evidence up-to-date.

We present the steps that the official authorities take to draw conclusions from scientific studies on foodhealth relations. Based on this analysis, we propose potential routes to automating at least parts of the process. First, the detection of relevant publications can be further automated. Secondly, the most important cause-effect relations can be extracted from these publications using techniques from automated summarization. These steps require creating dedicated controlled vocabularies. Finally, the process of grading the level of evidence can partly be automated using current practice in this area. The most challenging step will be to include contextual information, which is required for matching the evidence found with conditions of the real life case for which advice is sought. 


\section{Introduction}

The Personalized Nutrition and Health (PNH) Project aims to generate dietary advice for the consumer, based on evidence-based guidelines for healthy diets. The 'Dutch Dietary Guidelines 2015' [1], published by the Health Council of The Netherlands (Gezondheidsraad), describes food-health relations in detail, using scientific evidence from literature. These relations are needed to set up the guidelines and recommendations for consumers. In the PNH project, these guidelines are used in advisory software applications.

A methodology report accompanying the Dietary Guidelines [2] provides a description of the method that is used to find and assess scientific evidence. The entire process of finding and assessing literature is executed manually by the Health Council Committee, requiring much effort and time. However, new relations between food and health are discovered continuously over time and the guidelines are not updated with the new relations. As a consequence, the manually created guidelines lag behind progress made in science.

We argue that digital tools for finding and assessing scientific evidence, using (partly) automated data collection and reasoning, can make this process more efficient. It will allow software applications for dietary advice to use the most recent scientific evidence. Of course, this requires proper assessment of the quality and reliability of this evidence. This document describes the process, which at a later stage we aim to automate to some extent.

In 2010, the concept of dietary guidelines has been described by the European Food Safety Authority (EFSA) as follows: 'Food-Based Dietary Guidelines are science-based recommendations in the form of guidelines for healthy eating. They are primarily intended for consumer information, and as such, they should be appropriate for the region or country, culturally acceptable and practical to implement.

Moreover, they should be consistent, easily understood and memorable' [3]. The latest guidelines for the Dutch society were published in 2015 by Health Council of The Netherlands and satisfy the description provided by EFSA. This document gives an overview of the effect of food products on health parameters and risks for diseases. It focuses on the prevention of chronic diseases in the general, basically healthy population. Therefore, patients with specific diseases are outside the domain of these guidelines. This is also in line with the scope of the PNH project.

The guidelines are based on scientific evidence from literature. The committee of the dietary guidelines followed a very systematic method to find and assess that evidence. The outcomes of this process has been applied in the PNH project for giving personalized advice based on scientific evidence and by taking the consumer's health status into account. In addition, we also aimed to incorporate some of the latest scientific findings in this advice - for example at a yearly basis. However, keeping the evidence up-todate at such a pace would require too much time and effort to be feasible in practice.

Therefore we are investigating ways to automate the steps of finding and assessing scientific evidence. In order to make this process automatic, the manual steps of method have been carefully analysed.

In the first part of the report (Chapter 2), we explain the manual steps that the committee of the Health Council follows to construct the guidelines, by filtering and assessing evidence from literature. Chapter 3 gives clues about how to automate the process of searching for evidence and updating the evidence by looking at new literature for food health relations in future. 


\section{Methodology: finding and assessing evidence}

In this chapter, the method followed by the Health Council to find evidence-based food-health relations is presented.

\subsection{Types of studies and level of evidence}

This section is devoted to the procedure that the committee follows for the evaluation of the evidence. The overall flow of this process is presented in Figure 1.

The dietary guidelines focus on the general population, however, for children up to two years old and pregnant (or lactating) women separate dietary guidelines are relevant [1]. Patients with diseases can benefit from the general dietary guidelines, nevertheless, disease-specific dietary treatment guidelines can support dieticians when giving advice to patients. Since the scope of the guidelines is healthy people, the studies to look at in literature are limited to those in which the exposure to a certain food product was measured before the outcome of a disease is determined. The choices on population profile already determine the types of the articles or studies to focus on. That is, cross-sectional studies, case reports and most of the case-control studies are not considered [2].

Additionally, due to feasibility reasons, evidence from in vitro research and experimental animal studies are excluded. As those papers lead to conclusions about lab research or about the effects in animals, they do not necessarily extend to human subjects.

Studies that collect nutritional data prior to the onset of a disease can be either experimental or observational in nature [2]. The committee included all types of observational studies as well as experimental studies. Observation studies are called cohort studies. While describing experimental research, the committee primarily focused on randomized controlled trials (RCTs) with a control group. In scientific journals, the value of RCTs compared to cohort studies is still a debate. The pros and cons of RCTs and cohort studies are presented in Table 1. It shows that cohort studies can provide complementary information to the data obtained from RCTs. But, independently, a good quality RCT can give a basis for determining whether or not there is a causal relationship between the intervention and its effect. In addition, other types of studies than cohort or RCTs are graded with respect to the level of their evidence, see Table 2. The grading system that provides strength of recommendations based on evidence. In Table 2, the grading and level are presented together. However, an alternative option is to make an extra table of this because some grades can have multiple levels. For example $B$ is consistent for level 2 or 3 studies or extrapolations from level 1 studies ${ }^{1}$. It should be noted that the hierarchy of the level of evidence has some criticism in the literature. The levels of evidence provide a guide and the reader needs to be cautious when interpreting these results [13].

It is also important to keep in mind that coincidental circumstances in any study type can generate outcomes that give a false impression. The statistical significance level - the $p$-value - is an indication for the risk of a false positive outcome. In pooled analyses and meta-analysis, the findings from several original studies covering similar research questions are combined. Combining findings from several studies creates greater statistical power, that is, the relationship or effect estimations are more reliable

\footnotetext{
${ }^{1}$ https://www.cebm.ox.ac.uk/resources/levels-of-evidence/oxford-centre-for-evidence-based-medicine-levels-of-evidencemarch-2009
} 
compared to the original individual studies. Since existing literature in its full extent is hard to find and assess, focusing on pooled analyses, meta-analyses and systematic reviews helps the committee to ensure that the amount of work involved remains manageable. Therefore, the committee in [2] limits their literature reviews to a critical evaluation of systematic reviews, meta-analyses and pooled analyses. However, there is an exception for RCTs if they are implemented in groups of patients or in high-risk groups.

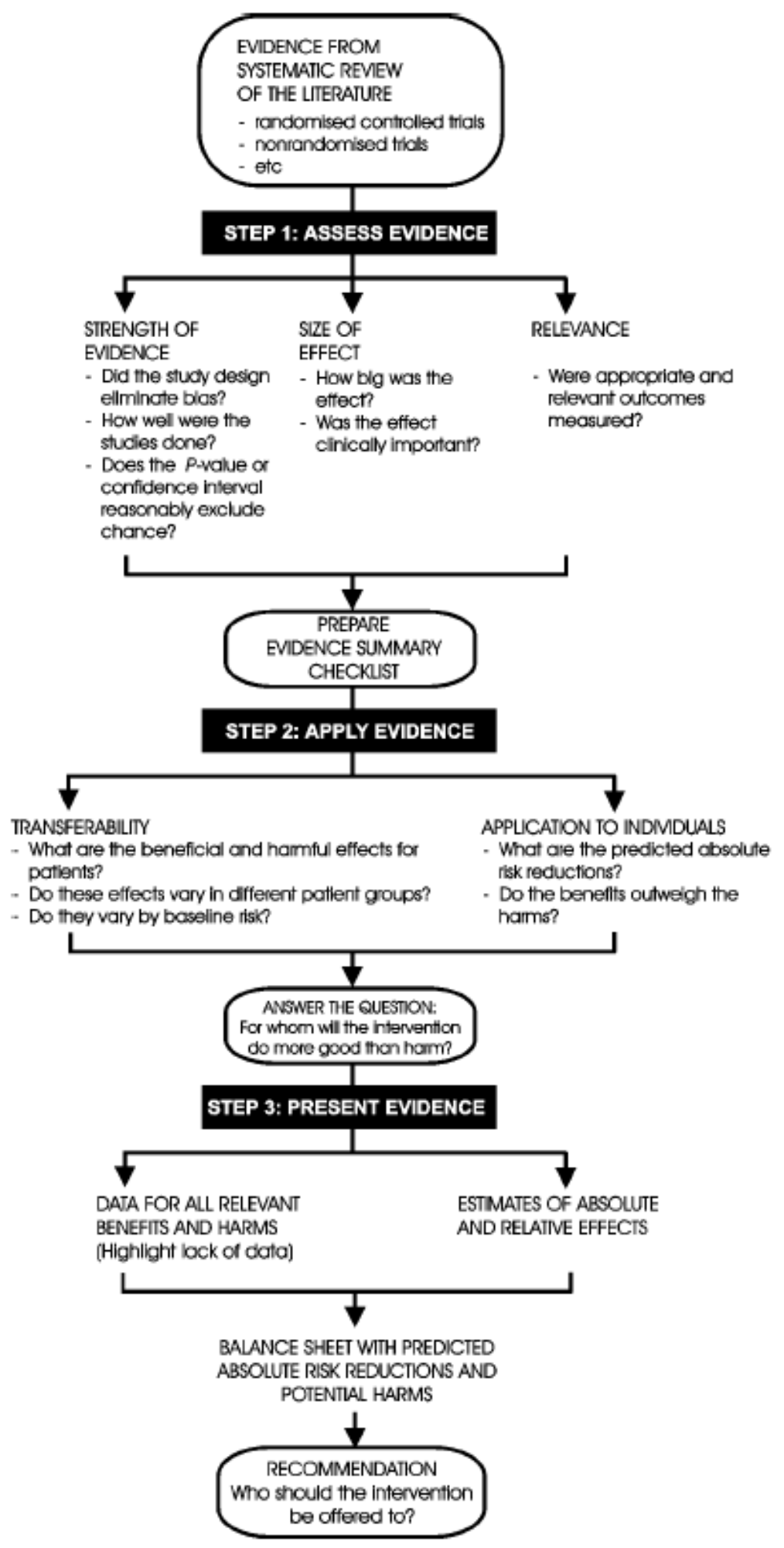

Figure 1 Process of tracing scientific evidence from literature [4]. 
Table 1 Pros and cons of RCTs and prospective cohort studies [2]

\begin{tabular}{|c|c|c|}
\hline & RCTs & Cohort studies \\
\hline Confounding & No & Can not be ruled out \\
\hline $\begin{array}{l}\text { Strength of the evidence regarding } \\
\text { causality }\end{array}$ & Strong & Less strong \\
\hline $\begin{array}{l}\text { Representativeness for general } \\
\text { population }\end{array}$ & Often limited & Generally good \\
\hline Measure of outcome & $\begin{array}{l}\text { Often risk factor, occasionally } \\
\text { morbidity/mortality }\end{array}$ & Usually morbidity/mortality \\
\hline Levels of exposure & $\begin{array}{l}\text { One or a few; } \\
\text { often relatively high }\end{array}$ & $\begin{array}{l}\text { All levels present in the study } \\
\text { population }\end{array}$ \\
\hline Number of participants & Limited & Large \\
\hline $\begin{array}{l}\text { Duration of study relative to time for } \\
\text { chronic diseases to develop }\end{array}$ & Short or limited & Long \\
\hline $\begin{array}{l}\text { Effects that occur (or mainly occur) in } \\
\text { specific stages of life and to a lesser } \\
\text { extent (or not at all) in other stages. }\end{array}$ & $\begin{array}{l}\text { More likely to be missed due to } \\
\text { limited duration of study }\end{array}$ & $\begin{array}{l}\text { More likely to be observed due } \\
\text { to extensive duration of study }\end{array}$ \\
\hline
\end{tabular}

Table 2 Level of evidence for different types of studies ${ }^{2}$

\begin{tabular}{|c|c|c|}
\hline Level & Criteria & $\begin{array}{l}\text { Grades of } \\
\text { recommendation }\end{array}$ \\
\hline $1 a$ & $\begin{array}{l}\text { Systematic reviews (with homogeneity) of RCT's or meta- } \\
\text { analyses }\end{array}$ & A \\
\hline $1 b$ & Individual RCT (with narrow confidence interval) & A \\
\hline $1 \mathrm{c}$ & All or none study & A \\
\hline $2 a$ & Systematic reviews (with homogeneity) of cohort studies & B \\
\hline $2 b$ & $\begin{array}{l}\text { Individual cohort studies or RCT's of less quality (e.g., }<80 \% \\
\text { follow-up) }\end{array}$ & B \\
\hline $3 a$ & Systematic reviews (with homogeneity) of case-control studies & B \\
\hline $3 b$ & Individual case-control study & B \\
\hline 4 & Case series and cohorts or case-control studies of less quality & C \\
\hline 5 & $\begin{array}{l}\text { Expert opinion (without explicit critical appraisal, or based on } \\
\text { physiology, bench research or "first principles") }\end{array}$ & D \\
\hline
\end{tabular}

\footnotetext{
${ }^{2}$ https://www.cebm.ox.ac.uk/resources/levels-of-evidence/oxford-centre-for-evidence-based-medicine-levels-of-evidence-
} march-2009

8 | ConfidentialWageningen Food \& Biobased Research-Report 2122 


\subsection{Aspects of health}

The aim of giving nutritional advice in general is to prevent the occurrence of health problems and diseases. To be most effective at the population level, the Health Council concentrates on prevailing occurrence of health issues with their dietary guidelines [1].

In the Netherlands, ten diseases are considered most important, in terms of mortality, years of potential life lost and burden of disease. These are coronary heart disease, stroke, heart failure, diabetes mellitus type 2 (T2DM), chronic obstructive pulmonary disease (COPD), breast cancer, colorectal cancer, lung cancer, dementia and cognitive decline, and depression. They also look at the 'causal risk factors' for at least one of these diseases. It has been shown that the risk factors systolic blood pressure, LDL cholesterol and body weight have a relationship with at least one of the following health problems: coronary heart disease, stroke, heart failure and diabetes mellitus type 2. However, no research data is available indicating the relationships between these risk factors and other diseases.

\subsection{Steps followed to find scientific evidence for the Dutch Dietary Guidelines 2015}

The first step in finding scientific evidence is to search for relevant publications in Pubmed. The following search strategy is applied:

1) Search query (basic format):

"nutritional factor" [Mesh] AND ("systematic review" [Publication Type] OR "meta-analysis"

[Publication Type])

2) Additional Mesh terms are added to design a better filter, such as synonyms of the nutritional factor or terms to direct the search, e.g. 'body weight', 'systolic blood pressure'. This will decrease the number of papers found.

3) Only 'meta-analysis' and 'systematic review' and 'comparative study' papers are considered. Other types such as 'prospective cohort study', 'controlled trial study' and 'case control study' are ignored.

4) The search is limited to species: "human".

Search is done manually, but it is possible to create a plain text which can be generated by PubMed to annotate the articles. This text can be indexed and used for automated research. After completing the search following the above strategy, the articles found are sometimes still irrelevant and an additional manual selection step is made by checking the titles of the papers.

Once a shortlist of potentially relevant articles has been made, the researchers dive into the papers to assess the evidence contained by them by summarizing the findings. Table 3 shows the attributes that are taken into account when annotating the documents. 
Table 3 Paper attributes given by the Committee [2]

\begin{tabular}{|c|c|}
\hline ke & Expla \\
\hline Published studies & $\begin{array}{l}\text { Here the Committee specifies the number of meta-analyses and the number of } \\
\text { cohort studies or RCTs. }\end{array}$ \\
\hline Heterogeneity & $\begin{array}{l}\text { Yes/No; if "Yes", then the Committee will provide an explanation, where possible. } \\
\text { Meta-analyses involve tests for heterogeneity between the original studies. If such } \\
\text { tests indicate that there is little or no heterogeneity }\left(\mathrm{I}^{2}<0.25\right) \text { then "No" is entered in } \\
\text { the summary table. Where there is moderate }\left(\mathrm{I}^{2} 0.25-0.50, \mathrm{p}<0.10\right) \text { or significant } \\
\left(\mathrm{I}^{2}>0.50 \text { and } \mathrm{p}<0.10\right) \text { heterogeneity, "Yes" appears in the summary table. Where } \\
\text { no heterogeneity test is available, the Committee assesses the degree of overlap } \\
\text { between the confidence intervals of the original studies or meta-analyses and the } \\
\text { direction of the risk estimates. }\end{array}$ \\
\hline $\begin{array}{l}\text { Strength of the } \\
\text { effect/relationship }\end{array}$ & $\begin{array}{l}\text { If it is possible to draw a conclusion about an association or effect, the Committee } \\
\text { specifies the effect estimate or risk assessment here, if possible in relation to intake } \\
\text { (or to changes in intake). }\end{array}$ \\
\hline Study population & $\begin{array}{l}\text { Here, in the case of cohort studies, the Committee gives details of the continent in } \\
\text { which the study took place (Europe, North America, Australia \& New Zealand, Asia). } \\
\text { Gender is specified if the published studies were restricted solely to men or solely to } \\
\text { women. In the case of RCTs, the Committee gives details of the patient group or } \\
\text { high-risk group, gender and age. }\end{array}$ \\
\hline
\end{tabular}

The conclusion about a certain food-health relation can be annotated with a number of predefined terms to qualify the evidence found. These terms are shown in Table 4.

\subsection{Example: dairy products and metabolic syndrome}

All systematic reviews or meta-analyses on which the guidelines for good nutrition related to dairy products are based, are described in the tables presented in Appendix I (in Dutch). The conclusions per parameter are listed in the summary table.

The RGV 2015 committee has looked at specific risk factors for which the causal relationship with at least one chronic disease has been demonstrated; these outcome measures are referred to in the advisory report as causal risk factors. It concerns systolic blood pressure, LDL cholesterol and body weight.

The following specific conclusions have been drawn from RGV 2015 and the background document on dairy products in relation to symbolic syndrome:

The committee concludes that it is plausible that the consumption of yogurt ( $\geq 60 \mathrm{~g} / \mathrm{d}$ vs. $<10 \mathrm{~g} / \mathrm{d}$ ) has a lower risk of diabetes (-15\%). 
Table 4 Expressions to qualify evidence found in literature [2]

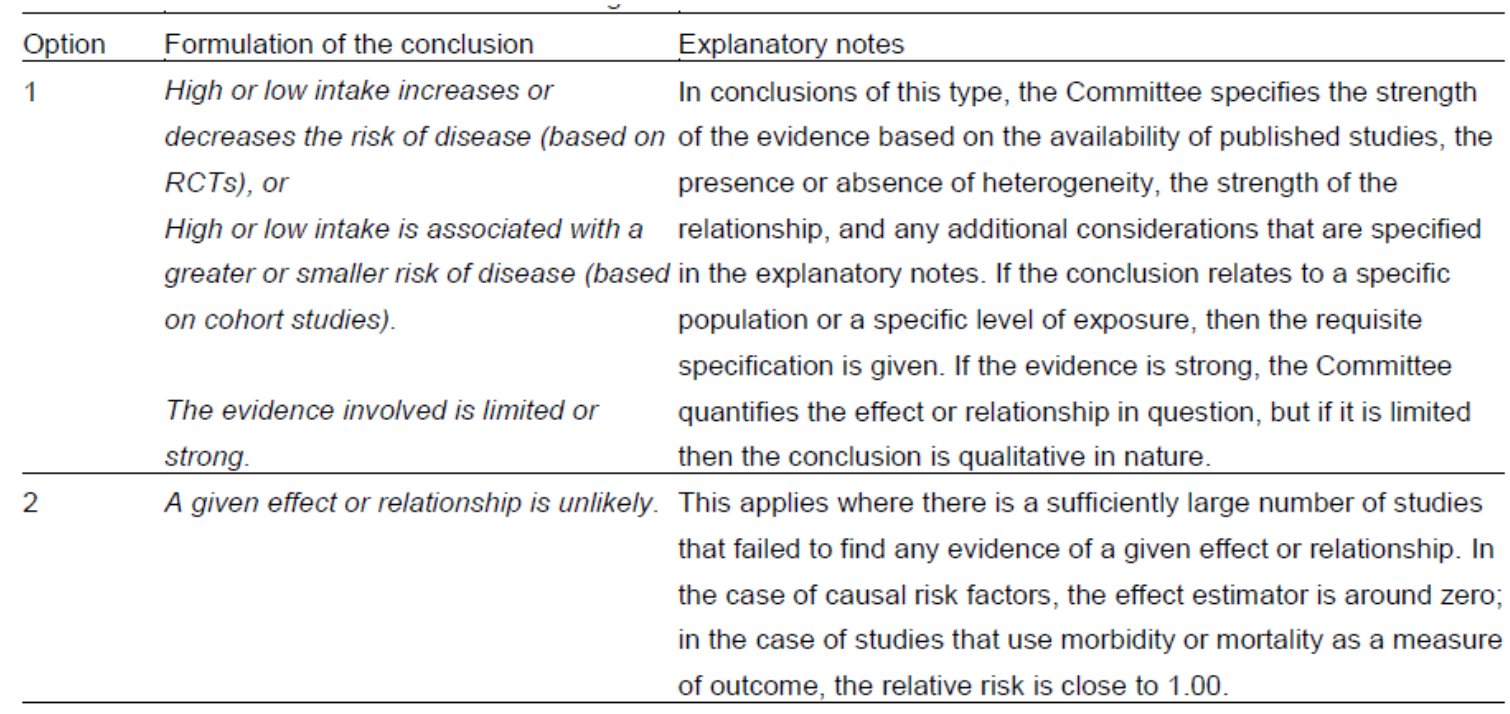

3 The effect or relationship is ambiguous. One or more of the following conditions is true:

1) A meta-analysis has revealed a substantial and unexplained level of heterogeneity.

2) There are substantial differences in the direction of effects or relationships between individual intervention studies or cohort studies.

$4 \quad$ There are too few studies to support

One or more of the following conditions is true: conclusions about a given effect or

1) Just a single original study was published relationship.

2) All published studies derive from a single research group, so they are not independent

3) The published studies are of insufficient quality to support a conclusion about the relationship or effect.

4) The published studies provide an insufficient basis to support the conclusion that a given relationship or effect exists, yet, by the same token, they cannot support the conclusion that a given relationship or effect is unlikely. 


\section{Potential ways to automate the process}

The guidelines document is formed by the Committee of the Dutch Health Council by inspecting the literature and translating and annotating the conclusions from a selection of documents. This process requires lots of resources and time. Moreover, the guidelines have to be updated frequently with the appearance of new literature. Within the PNH project, we aim to extend the existing evidence found by the committee with the latest findings by detecting and analysing the new literature automatically. We performed this process, roughly following the steps that the council follows. Along the way we identified which parts to the process can possibly automated. This is clearly quite a challenge, but we argue that some automation is possible or will be possible in the near future given the current developments in information technology.

\subsection{Finding publications}

The first step of the process is to detect and collect relevant publications. Several recent developments in information technology have created new opportunities for sharing and retrieving documents from all kinds of sources. For example, a number of Application Programming Interfaces (APIs) are available for accessing PubMed programmatically, allowing software tools to specify search actions. Figure 2 shows an example of a query we used in our study. The availability of such APIs enables the automated construction of complex queries, using domain knowledge, as for example available in a so-called Knowledge Graph. In the case of personalised nutrition, expert knowledge about nutrients, health parameters and health issues can be modelled in e.g. an (interoperable) standardized vocabulary to enrich these search queries. This would not only further automate this step, but also make it more effective. Developing knowledge graphs for this domain is ongoing research, for example in [6] and [7].

(Fabaceae[mesh term] or soy[tiab] or pulses[tiab]) AND (meta-analysis or "systematic review") AND (dietary or diet or nutritional or food or intake or supplement) NOT (Dcegnaa* OR child OR children OR animal OR plant[ti]) - 172 results (all covered)

\section{ALTERNATIVELY:}

1) (pulses[tiab] OR legume*[tiab] OR bean*[tiab] OR pea[tiab] OR peas[tiab] OR soy[tiab]) AND (meta-analysis OR "systematic review") AND (dietary OR diet OR nutritional OR food OR intake of supplement*) NOT (bregnan* OR child OR children OR animal OR plant[ti]) 180 results (all covered)

2) ((pulses[tiab] or legume*[tiab] or bean*[tiab] or pea[tiab] or peas[tiab]) AND (metaanalysis or "systematic review") AND (dietary or diet or nutritional or food or intake of supplement ${ }^{*}$ )) AND "last 10 years"[RDat] AND Humans[Mesh]) - 85 results (soy excluded, rest covered)

((soy[tiab] AND lung cancer [tiab]) AND (meta-analysis or "systematic review") AND (dietary or diet or nutritional or food or intake or supplement) ) - 3 results (soy papers covered)

Figure 2 An example of a search query related to the health impact of the consumption of legumes. 
Automatic search can detect relevant publications. Next, we can also extract the most informative paragraphs or sentences from these publications using Information Extraction techniques. For example in [8] a detailed vocabulary is used to create answers to user questions, selecting small text fragments from the found documents. Whether relevant fragments are found highly depends on the presence of relations between 'question' terms and 'answer' terms in the vocabulary. In a food-health vocabulary 'is_causing' or 'symptom_of' would be important relations when identifying related terms. In the food domain, certain products and ingredients (or rather amounts of them) could be ontologically related to certain heath parameters using such relations. In addition, metadata about the role of a paragraph (abstract, conclusion) can help to improve the quality of the answers found.

In other words, finding relevant papers and specific sections in those papers requires the availability of controlled vocabularies or knowledge graphs with annotations. Developing these is still a labour-intensive process, mostly relying on input from domain experts. However, it is also possible to extract terms from publications that have already been selected for specific food-health relations. This process can partly be automated with new methods for ontology extraction [9]. These methods are typically based on term frequency analysis and filtering out 'common terms' for a selected language. In addition, it is possible to use co-occurrence of terms to detect which terms are mutually related. If existing controlled vocabularies are available, they can be used to find qualified relations. However, the final assessment of the vocabularies still has to be left to domain experts.

\subsection{Automated summaries}

Finding documents and extracting paragraphs as-is is one thing, but identifying expressions that represent relations between a diet and a health status needs one further step. This information has to be extracted by selecting, combining and reformulating sentences from the original publication(s). Here, new developments in automated text summarisation using natural language processing (NLP) can play a role. For the health domain this is still in its infancy, due to the fact that much background knowledge is needed to distil and merge the proper arguments. Moreover, what is to be included in a summary is different for each considered case. For example, in our manual effort to find evidence from some relatively new claims it was not clear whether to include the source of a particular nutrient to include in the model. Figure 3 shows that nutrients impacting the LDL-level can be found in oats and barley or in pectin, but their impact level may be different.

\begin{tabular}{|c|c|c|c|c|}
\hline Specific nutrient & Parameter & Effect & Evidence & Level of evidence \\
\hline Betaglucanen uit haver en gerst & LDL & Gunstig & Groot & $1 a, 1 b$ \\
\hline Pectine & LDL & Gunstig & Groot & $1 a$ \\
\hline
\end{tabular}

\section{Figure 3 Excerpt of a collection of food-health relations that were manually extracted. The} first column mentions the nutrient source used in a particular study.

Sarker and Molla [10] provide a detailed analysis of the state of art in text summarisation for EvidenceBased Medicine (EBM). As the food-health domain is more specific than the health domain in general, we expect the suggested approaches to be more readily applicable for our purpose. They analyse seven tools for summarisation in the medical domain. The following elements appear to contribute to relative success of a tool.

- Applying supervised classification proves to be effective.

- Incorporating domain-specific semantic information contributes significantly.

- A focus on answering questions in real-life situations (rather than generating definitions only) is crucial. 
- Instead of using natural language the PICO (Problem/Population, Intervention, Comparison and Outcome) representation can be used for questions and answers.

- The ability to combine results from multiple related documents is needed.

- The systems should follow evidence-based guidelines (see next paragraph).

- Automatic polarity detection (stating whether a relation is positive, negative, neutral or no outcome) is feasible.

- Generated summaries should be brief.

Interestingly, Sarker and Molla do not explicitly discuss the distinction between the (causal) relation as such, and the context in which it has been observed. For example, the source of food products as illustrated in Figure 3 can be important metadata. In our view, deciding on which context information to include will be the major bottleneck in creating automated summarisation tools.

\subsection{Assessing evidence levels}

After having extracted science-based food-health effects in literature, we need to judge the strength of this evidence in relation to (new) guidelines. Three aspects determine the level of scientific evidence, i.e., quality, quantity and coherence [11].

Quantity and coherence are relatively easy to determine semi-automatically if the extraction process has been done properly. They express the number of different sources (for example 'Published studies' in Table 3) that confirm a selected effect ('Heterogeneity No' in Table 3 and options 2, 3 and 4 in Table 4). It becomes more complicated if also contradicting effects are found. This either means that studies were done in different circumstances, or that they were not properly executed. For comparison of circumstances, it may be necessary to search for additional information in the publications. Methodological inadequacies can in general not be traced in the text, even by human experts, often because they have not been reported. In that case, the only conclusion possible will be that a contradiction has been found and that additional scientific research is needed.

Quality is more difficult to establish, as it relates to (1) how the research was performed and (2) whether it matches the (conditions) of the original question. A first step to determine the methodological quality is by looking at the standard classification of studies, as commonly used in medical practice. This classification is illustrated in Figure $4^{3}$, and was listed in Table 2 . The latter also assigns numerical values to each level of evidence. Since this information is readily available as metadata, it can in principle also be used in automated analysis. For example, in [12] it is shown that a rule-based approach can be fairly effective. In addition, the size of the study population is a quite straightforward measure for the quality of the study. For this parameter, a lower limit is even available using standard statistical methods ${ }^{4}$.

Comparing the conditions and circumstances of the consulted scientific studies with those of the original question is a challenge that needs further research. For example, do the study population and the target audience match (gender, age, culture, health status, etc.)? Do the food products, ingredients, samples match on both sides? The relevance of evidence found strongly depends on such similarities. However, automatically extracting and comparing this information is hard. A knowledge graph that represents most 'circumstantial' parameters would certainly assist in performing this task.

\footnotetext{
${ }^{3}$ https://www.researchgate.net/figure/Hierarchy-of-evidence-pyramid-The-pyramidal-shape-qualitatively-integrates-theamount-of_fig1_311504831

${ }^{4}$ https://en.wikipedia.org/wiki/Sample_size_determination
} 


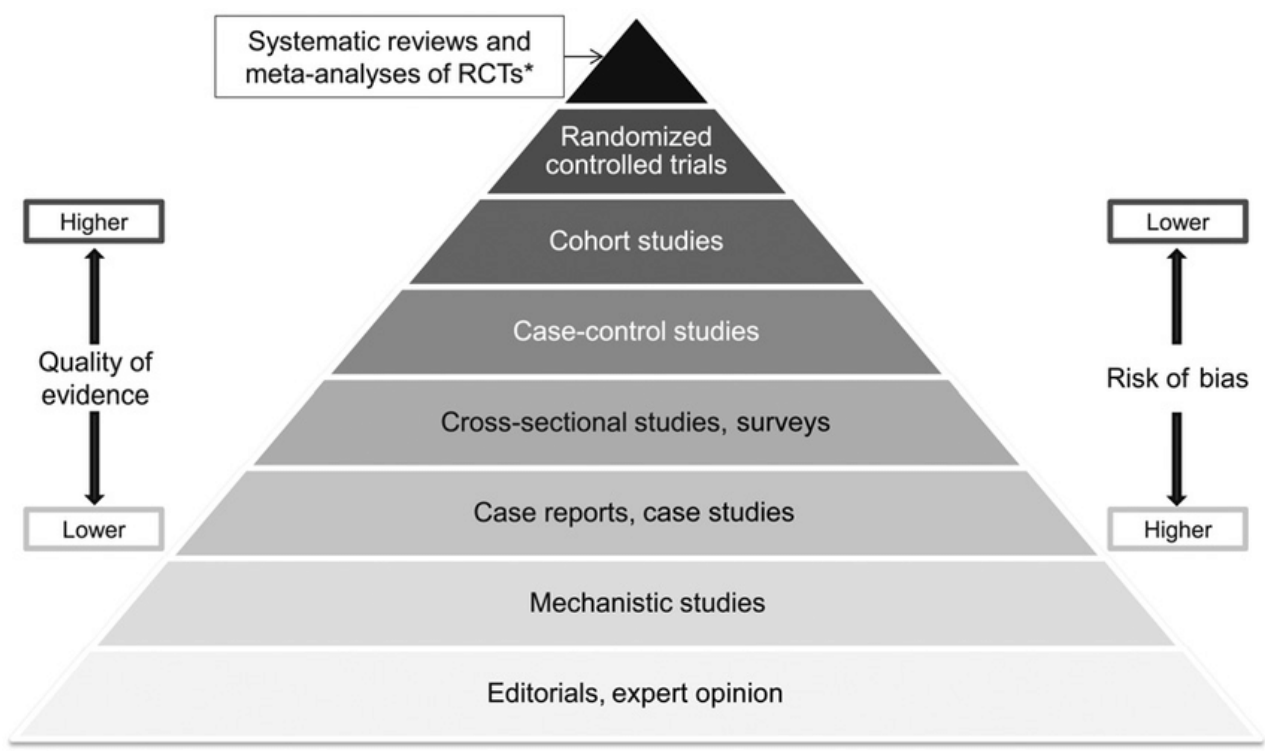

Figure 4 Levels of evidence for different types of studies, with systematic reviews of randomized control trials providing the highest level of evidence ${ }^{3}$. 


\section{Conclusion}

Although digital personalised dietary advice is increasingly popular, reference to scientific knowledge is often missing or only given indirectly. Therefore, new insights are either neglected or taken up without adequate scientific rigour. This is due to the fact that finding food health relations and the associated level of scientific evidence is difficult, laborious and time consuming. We have presented the steps which are followed by the official authorities to draw conclusions from scientific studies on food-health relations. Based on this analysis, potential routes to automating at least parts of the process are proposed in this report. As a first step, the detection of relevant publications can be further automated. After determining relevant publications, the most important cause-effect relations can be extracted from these publications using techniques from automated summarization. For this automation dedicated controlled vocabularies are required. Finally, the process of grading the level of evidence can partly be automated using current practice in this area. The most challenging step will be to include contextual information, which is required for matching the evidence found with conditions of the real life case for which advice is sought. 


\section{Literature}

[1] Health Council of The Netherlands, Dutch Dietary Guidelines 2015, The Hague: Health Council of the Netherlands, Publication no 2015/26E, The Hague, 2015.

[2] Methodology for the evaluation of the evidence for the Dutch dietary guidelines 2015, Ministry of Health, Welfare and Sport, A15/03E, The Hague, 2015.

[3] EFSA (European Food Safety Authority), Scientific Opinion on establishing Food-Based Dietary Guidelines, EFSA Panel on Dietetic Products, Nutrition, and Allergies (NDA), 2010.

[4] How to use the evidence: assessment and application of scientific evidence Handbook series on preparing clinical practice guidelines, National Health and Medical Research Council Autralia, 2000.

[5] Grobbee D.E., Hoes A. W. Clinical epidemiology. Principles, methods, and applications for clinical research. Jones and Bartlett Publ, Inc., 2007.

[6] D. M. Dooley et al., "FoodOn: a harmonized food ontology to increase global food traceability, quality control and data integration," NPJ Sci Food, vol. 2, p. 23, 2018, doi: 10.1038/s41538018-0032-6.

[7] Rotmensch, Maya \& Halpern, Yoni \& Tlimat, Abdulhakim \& Horng, Steven \& Sontag, David. Learning a Health Knowledge Graph from Electronic Medical Records. Scientific Reports, 7, 2017. DOI: $10.1038 /$ s41598-017-05778-z.

[8] Willems, D., et al. (2015). "From science to practice: Bringing innovations to agronomy and forestry." Journal of Agricultural Informatics 6(4).

[9] Asim MN, Wasim M, Khan MUG, Mahmood W, Abbasi HM. A survey of ontology learning techniques and applications. Database (Oxford). 2018;2018: bay101. Published 2018 Jan 1. doi:10.1093/database/bay10.

[10] Sarker, Abeed \& Molla Aliod, Diego \& Paris, Cécile. Automated text summarisation and evidence-based medicine: A survey of two domains. 2017.

[11] Glasofer, Amy DNP, RN, NE-BC; Townsend, Ann B. DrNP, RN, ANP-C, CNS-C Determining the level of evidence, Nursing Critical Care: November 2019 - Volume 14 - Issue 6 - p 22-25, doi: 10.1097/01.CCN.0000580120.03118.1d

[12] Huang Z, Hu Q, ten Teije A, and van Harmelen F, Identifying Evidence Quality for Updating Evidence-based Medical Guidelines. Knowledge Representation for Health Care, p 51-64, Springer 2015.

[13] Burns PB, Rohrich RJ, Chung KC. The levels of evidence and their role in evidence-based medicine. Plast Reconstr Surg. 2011;128(1):305-310. doi:10.1097/PRS.0b013e318219c171. 


\section{APPENDIX 1}

The tables below present the information (in Dutch) as used by the commission to determine the relation between dairy consumption and the occurrence of diabetes. 
Table 1: Systematische reviews en meta-analyses RGV zuivel in relatie tot lichaamsgewicht en/of middelomtrek

\begin{tabular}{|c|c|c|c|c|c|c|}
\hline Referentie & Studie design & $\begin{array}{l}\text { Aantal studies en } \\
\text { deelnemers }\end{array}$ & Interventie(s) & Controle(s) & Bijzonderheden & $\begin{array}{l}\text { Effect van interventie(s) ten opzichte van } \\
\text { controle(s) }\end{array}$ \\
\hline $\begin{array}{l}\text { Benatar et al, } \\
2013^{a}\end{array}$ & $\begin{array}{l}\text { Meta-analyse van RCT's } \\
\text { PRISMA design }\end{array}$ & $\begin{array}{l}18 \mathrm{RCT} \text { 's. } \\
1,629 \text { ( } 82 \% \text { vrouw) } \\
\text { gezonde participanten of } \\
\text { participanten met } \\
\text { overgewicht of obesitas. }\end{array}$ & $\begin{array}{l}2,5 \text { tot } 5 \text { porties magere } \\
\text { en halfvolle of volle } \\
\text { zuivelproducten per dag. }\end{array}$ & $\begin{array}{l}\text { Gebruikelijke } \\
\text { voedingspatroon en/of 0-1 } \\
\text { portie zuivel per dag en/of } \\
\text { plantaardige oliën. }\end{array}$ & $\begin{array}{l}\text { Heterogeniteit } \\
\text { gewicht: } 32 \% \\
\text { Heterogeniteit } \\
\text { middelomtrek: } 74 \%\end{array}$ & $\begin{array}{l}\text { Verhoogde intake van zowel magere, halfvolle en } \\
\text { volle zuivelproducten per dag, zonder andere } \\
\text { dieetinterventies, wordt geassocieerd met een } \\
\text { significante lichte stijging in lichaamsgewicht } \\
\text { (gemiddeld verschil: }+0,60 \mathrm{~kg}, 95 \% \mathrm{Bl}: 0,30 \text { tot } 0,90 \\
\mathrm{~kg}, \mathrm{P}=<0,0001 \text { ). }\end{array}$ \\
\hline
\end{tabular}

Geen significante veranderingen in middelomtrek waren zichtbaar onder 440 participanten in zes interventiestudies.

\begin{tabular}{|c|c|c|c|c|c|c|}
\hline $\begin{array}{l}\text { Abargouei et al, } \\
2012^{\mathrm{b}}\end{array}$ & $\begin{array}{l}\text { Systematische review \& } \\
\text { meta-analyse van RCT's }\end{array}$ & $\begin{array}{l}14 \mathrm{RCT}^{\prime} \text { s voor } \\
\text { lichaamsgewicht, waarvan } \\
8 \mathrm{RCT} \text { 's ook middelomtrek. } \\
883 \text { participanten. }\end{array}$ & $\begin{array}{l}1 \text { tot } 4 \text { porties } \\
\text { zuivelproducten per dag. }\end{array}$ & $\begin{array}{l}\text { Gebruikelijke } \\
\text { voedingspatroon. }\end{array}$ & $\begin{array}{l}\text { Heterogeniteit } \\
\text { gewicht: } 42,1 \% \\
\text { Heterogeniteit } \\
\text { middelomtrek: 53,4\% }\end{array}$ & $\begin{array}{l}\text { De voorafgaande analyse indiceerde in eerste } \\
\text { instantie significant gewichtsverlies en een grotere } \\
\text { afname in middelomtrek in de interventie } \\
\text { vergeleken met de controle. Echter, significante } \\
\text { heterogeniteit was aanwezig tussen de studies. Na } \\
\text { subgroep analyse, was er in studies zonder } \\
\text { energierestrictie geen significant effect van } \\
\text { zuivelinname op lichaamsgewicht en middelomtrek } \\
\text { zichtbaar. }\end{array}$ \\
\hline
\end{tabular}

\begin{tabular}{|c|c|c|c|c|c|c|}
\hline $\begin{array}{l}\text { Chen et al, } \\
2012^{\mathrm{b}}\end{array}$ & $\begin{array}{l}\text { Meta-analyse van RCT's } \\
\text { PRISMA design }\end{array}$ & $\begin{array}{l}14 \text { RCT's voor } \\
\text { lichaamsgewicht. } \\
\text { 1,614 participanten. }\end{array}$ & $\begin{array}{l}1 \text { tot } 6,5 \text { porties } \\
\text { zuivelproducten per dag } \\
\text { zoals magere melk, } \\
\text { halfvolle melk, magere } \\
\text { melkpoeder, yoghurt en } \\
\text { kaas. }\end{array}$ & $\begin{array}{l}\text { Ad libitum gebruikelijke } \\
\text { voeding (zonder energie } \\
\text { restricties) of isocalorische } \\
\text { sucrosedrank óf fruitsap. }\end{array}$ & Heterogeniteit: 70,9\% & $\begin{array}{l}\text { Geen significant effect gevonden van zuivelinname } \\
\text { op lichaamsgewicht zonder energierestrictie op de } \\
\text { lange termijn (gemiddeld verschil: }+0,39 \mathrm{~kg}, 95 \% \mathrm{BI} \text { : } \\
-0,36 \text { tot } 1,13 \mathrm{~kg} \text { ). }\end{array}$ \\
\hline
\end{tabular}

${ }^{a}$ Benatar et al. 2013 onderzoekt 13 studies, die ook door Chen et al. 2012 zijn onderzocht.

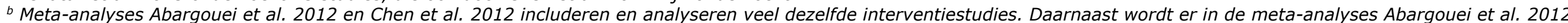
onderscheidt gemaakt tussen de interventiestudies die uitgaan van de parameters lichaamsgewicht en middelomtrek. 
Tabel 2: Systematische reviews en meta-analyses RGV zuivel in relatie met LDL-cholesterolgehalte

\begin{tabular}{|c|c|c|c|c|c|c|}
\hline Referentie & Studie design & Aantal studies en deelnemers & Interventie(s) & Controle(s) & Bijzonderheden & Effect van interventie(s) ten opzichte van controle(s) \\
\hline $\begin{array}{l}\text { Benatar et al, } \\
\text { 2013* }\end{array}$ & $\begin{array}{l}\text { Meta-analyse van } \\
\text { RCT's } \\
\text { PRISMA design }\end{array}$ & $\begin{array}{l}9 \text { RCT's } \\
702 \text { gezonde participanten of } \\
\text { participanten met overgewicht } \\
\text { of obesitas. }\end{array}$ & $\begin{array}{l}2,5 \text { tot } 5 \text { porties magere } \\
\text { en halfvolle of volle } \\
\text { zuivelproducten per dag. }\end{array}$ & $\begin{array}{l}\text { Gebruikelijke } \\
\text { voedingspatroon en/of } \\
0-1 \text { portie zuivel per dag } \\
\text { en/of plantaardige oliën. }\end{array}$ & Heterogeniteit: $64 \%$ & $\begin{array}{l}\text { Er was geen significant verschil in LDL-cholesterol bij } \\
\text { een hogere inname van zowel magere, halfvolle en volle } \\
\text { zuivelproducten per dag (gemiddeld verschil: }+1,85 \\
\mathrm{mg} / \mathrm{dL}, 95 \% \mathrm{BI}:-2,89 \text { tot } 6,60 \mathrm{mg} / \mathrm{dL} \text { ). }\end{array}$ \\
\hline $\begin{array}{l}\text { Agerholm- } \\
\text { Larsen et al, } \\
2000\end{array}$ & $\begin{array}{l}\text { Meta-analyse van } \\
\text { RCT's }\end{array}$ & $\begin{array}{l}5 \text { RCT's } \\
368 \text { participanten met normo- } \\
\text { of hyper-cholesterolemie. }\end{array}$ & $\begin{array}{l}200 \text { tot } 450 \mathrm{ml} \text { met } \\
\text { Causido } \\
\text { gefermenteerde yoghurt } \\
\text { per dag. }\end{array}$ & $\begin{array}{l}\text { Placebo: aangezuurde } \\
\text { yoghurt }\end{array}$ & $\begin{array}{l}\text { Heterogeniteit: - Q- } \\
\text { test. } \\
\text { Echter waren er in } \\
\text { deze analyse alleen } \\
\text { kort durende } \\
\text { onderzoeken (1-2 } \\
\text { maanden) } \\
\text { opgenomen. }\end{array}$ & $\begin{array}{l}\text { Een significante verlaging van het LDL- } \\
\text { cholesterolgehalte was zichtbaar bij de inname van } \\
\text { Causido gefermenteerde yoghurt in vergelijking met } \\
\text { de inname van aangezuurde yoghurt (gemiddeld } \\
\text { verschil: }-0,25 \mathrm{mmol} / \mathrm{L}, 95 \% \mathrm{Bl}:-0,48 \text { tot }-0,01 \mathrm{mmol} / \mathrm{l} \text {, } \\
\mathrm{P}=<0,05 \text { ). }\end{array}$ \\
\hline
\end{tabular}

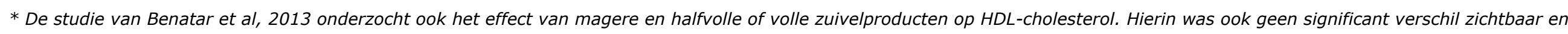
heterogeniteit (0\%) was contant. 
Tabel 3: Systematische reviews en meta-analyses RGV zuivel in relatie met systolische en diastolische bloeddruk*

\begin{tabular}{|c|c|c|c|c|c|c|}
\hline Referentie & Studie design & Aantal studies en deelnemers & Interventie(s) & Controle(s) & Bijzonderheden & Effect van interventie(s) ten opzichte van controle(s) \\
\hline $\begin{array}{l}\text { Benatar et al, } \\
2013\end{array}$ & $\begin{array}{l}\text { Meta-analyse van } \\
\text { RCT's } \\
\text { PRISMA design }\end{array}$ & $\begin{array}{l}7 \text { RCT's } \\
711 \text { gezonde participanten of } \\
\text { participanten met overgewicht } \\
\text { of obesitas. }\end{array}$ & $\begin{array}{l}3 \text { tot } 4 \text { porties magere } \\
\text { en halfvolle of volle } \\
\text { zuivelproducten per dag. }\end{array}$ & $\begin{array}{l}\text { Gebruikelijke } \\
\text { voedingspatroon en/of } \\
\text { max 1,5 portie zuivel per } \\
\text { dag en/of plantaardige } \\
\text { oliën. }\end{array}$ & $\begin{array}{l}\text { Heterogeniteit } \\
\text { systolische bloeddruk: } \\
0 \% \\
\text { Heterogeniteit } \\
\text { diastolische bloeddruk: } \\
40 \%\end{array}$ & $\begin{array}{l}\text { In alle onderzochte studies, was er geen significant } \\
\text { verandering tussen interventie en controle zichtbaar in } \\
\text { zowel systolische- }(-0,4 \mathrm{mmHg}, 95 \% \mathrm{BI}:-1,6 \text { tot } 0,8 \\
\mathrm{mmHg}) \text { als diastolische }(-0,45 \mathrm{mmHg}, 95 \% \mathrm{Bl}:-1,7 \text { tot } \\
0,8 \mathrm{mmHg}) \text { bloeddruk. Ook na stratificatie van duur van } \\
\text { interventie, laag/hoog vetgehalte of lichaamsgewicht } \\
\text { van deelnemers, geen significante verandering van } \\
\text { bloeddruk was zichtbaar. }\end{array}$ \\
\hline $\begin{array}{l}\text { Dong et al, } \\
2013\end{array}$ & $\begin{array}{l}\text { Systematische } \\
\text { review en meta- } \\
\text { analyse van RCT's } \\
\text { PRISMA design }\end{array}$ & $\begin{array}{l}13 \mathrm{RCT} \text { 's } \\
702 \text { participanten. }\end{array}$ & $\begin{array}{l}100 \text { tot } 450 \mathrm{ml} \\
\text { gefermenteerde } \\
\text { zuivelproducten per dag. }\end{array}$ & $\begin{array}{l}\text { Placebo: aangezuurde } \\
\text { yoghurt }\end{array}$ & $\begin{array}{l}\text { Heterogeniteit } \\
\text { systolische bloeddruk: } \\
24,1 \% \\
\text { Heterogeniteit } \\
\text { diastolische bloeddruk: } \\
29 \%\end{array}$ & 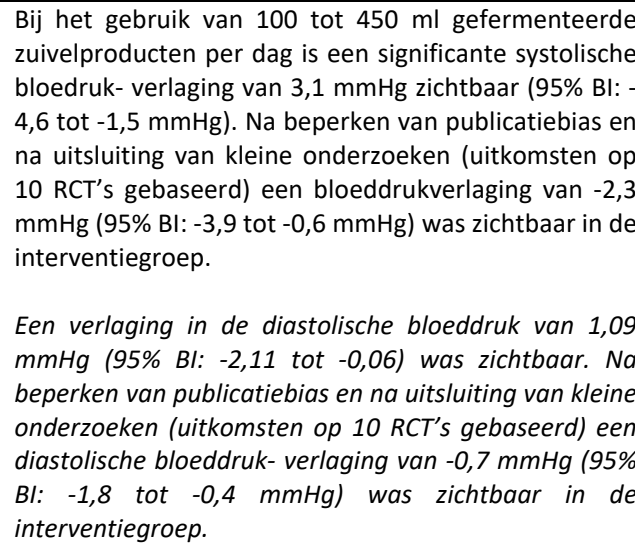 \\
\hline
\end{tabular}

* In de richtlijnen goede voeding 2015 wordt er uitgegaan van alleen de systolische bloeddruk. Hierin zijn nu ook de uitkomsten van diastolische bloeddruk meegenomen. 
Tabel 4a: Systematische reviews en meta-analyses RGV totale zuivel in relatie met nuchter bloedsuikergehalte en/of risico op T2DM

\begin{tabular}{|c|c|c|c|c|c|}
\hline Referentie & Studie design & Aantal studies en deelnemers & Blootstelling & Bijzonderheden & Effect van interventie(s) ten opzichte van controle(s) \\
\hline Chen et al, 2014 & $\begin{array}{l}\text { Meta-analyse van cohorts } \\
\text { PRISMA design }\end{array}$ & $\begin{array}{l}14 \text { cohorts } \\
383,024 \text { participanten }\end{array}$ & $\begin{array}{l}\text { Per portie (ca. } 177 \text { gram) totale } \\
\text { zuivel per dag. } \\
\text { Q4 vs. Q1 (hoge vs. lage } \\
\text { inname) }\end{array}$ & $\begin{array}{l}\text { Heterogeniteit: } 58,8 \\
\%\end{array}$ & $\begin{array}{l}\text { Er zijn geen aanwijzingen gevonden voor een verband tussen de } \\
\text { inname van totale zuivel en het risico of diabetes mellitus type } \\
2 \text { (RR: } 0,98,95 \% \text { BI: } 0,96 \text { tot } 1,01) \text {. }\end{array}$ \\
\hline Gao et al, $2013^{*}$ & $\begin{array}{l}\text { Systematische review en } \\
\text { meta-analyse van cohorts } \\
\text { PRISMA design }\end{array}$ & $\begin{array}{l}7 \text { cohorts } \\
157,880 \text { participanten }\end{array}$ & $\begin{array}{l}\text { Hoge vs. lage inname totale } \\
\text { melk inname }\end{array}$ & $\begin{array}{l}\text { Heterogeniteit: } 51,8 \\
\%\end{array}$ & $\begin{array}{l}\text { Geen verband was zichtbaar tussen de inname van totale melk } \\
\text { en het risico op diabetes mellitus type } 2 \text { (RR: } 0,89,95 \% \text { Bl: } 0,78 \\
\text { tot 1,01). }\end{array}$ \\
\hline Aune et al, 2013* & Meta-analyse van cohorts & $\begin{array}{l}7 \text { cohorts } \\
167,982 \text { participanten }\end{array}$ & $\begin{array}{l}\text { Hoge vs. lage inname totale } \\
\text { melk inname }\end{array}$ & $\begin{array}{l}\text { Heterogeniteit: } \quad 70,5 \\
\%\end{array}$ & $\begin{array}{l}\text { Geen verband was zichtbaar tussen de inname van totale melk } \\
\text { en het risico op diabetes mellitus type } 2 \text { (RR: } 0,87,95 \% \text { BI: } 0,70 \\
\text { tot } 1,07 \text { ). }\end{array}$ \\
\hline
\end{tabular}

$R R$ : relative risk $=$ risicoschatting

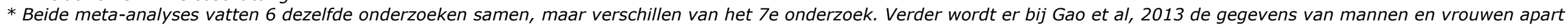
geanalyseerd. 


\section{Tabel 4b: Systematische reviews en meta-analyses RGV volle zuivel in relatie met nuchter bloedsuikergehalte en/of risico op T2DM}

\begin{tabular}{|c|c|c|c|c|c|}
\hline Referentie & Studie design & Aantal studies en deelnemers & Blootstelling & Bijzonderheden & Effect van interventie(s) ten opzichte van controle(s) \\
\hline Chen et al, 2014 & $\begin{array}{l}\text { Meta-analyse van cohorts } \\
\text { PRISMA design }\end{array}$ & $\begin{array}{l}3 \text { cohorts } \\
194,458 \text { participanten }\end{array}$ & $\begin{array}{l}\text { Per portie (ca. } 177 \text { gram) totale } \\
\text { zuivel per dag. } \\
\text { Q4 vs. Q1 (hoge vs. lage } \\
\text { inname) }\end{array}$ & - & $\begin{array}{l}\text { Er zijn geen aanwijzingen gevonden voor een verband tusser } \\
\text { de inname van volle zuivelproducten en het risico of diabetes } \\
\text { mellitus type } 2 \text { (RR: } 1,00,95 \% \text { Bl: } 0,95 \text { tot } 1,06 \text { ). }\end{array}$ \\
\hline Gao et al, 2013 & $\begin{array}{l}\text { Systematische review en } \\
\text { meta-analyse van cohorts } \\
\text { PRISMA design }\end{array}$ & $\begin{array}{l}8 \text { cohorts } \\
260,700 \text { participanten }\end{array}$ & Hoge vs. lage inname & $\begin{array}{l}\text { Heterogeniteit voor } \\
\text { volle zuivelproducten: } \\
38,1 \%\end{array}$ & $\begin{array}{l}\text { Geen verband was zichtbaar tussen de inname van volle } \\
\text { zuivelproducten en het risico op diabetes mellitus type } 2 \text { (RR } \\
0,95,95 \% \text { BI: } 0,85 \text { tot } 1,07 \text { ). }\end{array}$ \\
\hline Aune et al, 2013 & Meta-analyse van cohorts & $\begin{array}{l}8 \text { cohorts } \\
196,799 \text { participanten }\end{array}$ & Hoge vs. lage inname & Heterogeniteit: $15,9 \%$ & $\begin{array}{l}\text { Geen verband was zichtbaar tussen de inname van volle } \\
\text { zuivelproducten en het risico op diabetes mellitus type } 2 \text { (RR } \\
0,96,95 \% \text { BI: } 0,87 \text { tot } 1,06 \text { ). }\end{array}$ \\
\hline Chen et al, 2014 & $\begin{array}{l}\text { Meta-analyse van cohorts } \\
\text { PRISMA design }\end{array}$ & $\begin{array}{l}3 \text { cohorts } \\
194,458 \text { participanten }\end{array}$ & $\begin{array}{l}\text { Hoge vs. lage inname volle } \\
\text { melk inname }\end{array}$ & $\overline{-}$ & $\begin{array}{l}\text { Er zijn wat aanwijzingen voor een verband tussen de inname } \\
\text { van volle melkproducten en het risico op diabetes type } 2 \text { (RR } \\
1,08,95 \% \text { Bl: } 1,02 \text { tot } 1,14) \text {. Echter, de auteurs noemen dat } \\
\text { mogelijk reverse causation de bevindingen kan vertekenen } \\
\text { deelnemers die gedurende de follow-up een hoog } \\
\text { cholesterolgehalte of hoge bloeddruk hun voedingspatroon } \\
\text { hebben veranderd en juist meer halfvolle en magere } \\
\text { melkproducten zijn gaan eten. Wanneer de } \\
\text { voedingsvragenlijsten van deze deelnemers niet werder } \\
\text { meegenomen, werd het RR minder groot (RR: } 1,03,95 \% \text { BI } \\
0,99 \text { tot } 1,07) \text {. }\end{array}$ \\
\hline $\begin{array}{l}\text { Tong et al, } \\
2011^{*}\end{array}$ & Meta-analyse van cohorts & $\begin{array}{l}5 \text { cohorts } \\
174,424 \text { participanten }\end{array}$ & $\begin{array}{l}\text { Hoge vs. lage inname volle } \\
\text { melk inname }\end{array}$ & Heterogeniteit: $29,7 \%$ & $\begin{array}{l}\text { Geen verband was zichtbaar tussen de inname van volle } \\
\text { melkproducten en het risico op diabetes mellitus type } 2 \text { (RR } \\
0,95,95 \% \text { Bl: } 0,86 \text { tot } 1,05 \text { ). }\end{array}$ \\
\hline Gao et al, 2013 & $\begin{array}{l}\text { Systematische review en } \\
\text { meta-analyse van cohorts } \\
\text { PRISMA design }\end{array}$ & $\begin{array}{l}4 \text { cohorts } \\
88,323 \text { participanten }\end{array}$ & $\begin{array}{l}\text { Hoge vs. lage inname volle } \\
\text { melk inname }\end{array}$ & Heterogeniteit: $0 \%$ & $\begin{array}{l}\text { Geen verband was zichtbaar tussen de inname van volle } \\
\text { melkproducten en het risico op diabetes mellitus type } 2 \text { (RR } \\
1,12,95 \% \text { BI: } 0,99 \text { tot } 1,27) \text {. }\end{array}$ \\
\hline
\end{tabular}


Geen significant verband was zichtbaar tussen de inname van volle melkproducten en het risico op diabetes mellitus type 2 (RR: 1,12, 95\% BI: 0,99 tot 1,27). Mogelijk zijn er aanwijzingen (RR: $1,12,95 \%$ Bl: 0,99 tot 1,27 ). Mogelijk zijn er aanwijzingen voor een niet-lineair verband tussen volle melkproducten en
het risico op diabetes type 2 , met een stijgend risico bij het hoge gebruik vanaf 40 tot 50 gram per dag.

$R R$ : relative risk $=$ risicoschatting

* Beide meta-analyses vatten 3 dezelfde onderzoeken samen. 
Tabel 4c: Systematische reviews en meta-analyses RGV magere en halfvolle zuivel in relatie met nuchter bloedsuikergehalte en/of risico op T2DM

\begin{tabular}{|c|c|c|c|c|c|}
\hline Referentie & Studie design & Aantal studies en deelnemers & Blootstelling & Bijzonderheden & Effect van interventie(s) ten opzichte van controle(s) \\
\hline Chen et al, 2014 & $\begin{array}{l}\text { Meta-analyse van cohorts } \\
\text { PRISMA design }\end{array}$ & $\begin{array}{l}3 \text { cohorts } \\
194,458 \text { participanten }\end{array}$ & Hoge vs. lage inname. & - & $\begin{array}{l}\text { Er zijn geen aanwijzingen voor een verband tussen de inname } \\
\text { van magere en halfvolle zuivelproducten en het risico op } \\
\text { diabetes type } 2 \text { (RR: } 1,00,95 \% \mathrm{Bl}: 0,94 \text { tot } 1,05 \text { ). De auteurs } \\
\text { noemen dat mogelijk reverse causation de bevindingen kan } \\
\text { vertekenen: deelnemers die gedurende de follow-up een hoog } \\
\text { cholesterolgehalte of hoge bloeddruk hun voedingspatroon } \\
\text { hebben veranderd en juist meer halfvolle en magere } \\
\text { zuivelproducten zijn gaan eten. Daarnaast hebben de auteurs } \\
\text { niet specifiek voor magere en halfvolle zuivel het effect op de } \\
\text { risicoschatting onderzocht. }\end{array}$ \\
\hline Aune et al, 2013 & Meta-analyse van cohorts & $\begin{array}{l}10 \text { cohorts } \\
278,875 \text { participanten }\end{array}$ & Hoge vs. lage inname. & Heterogeniteit: $0 \%$ & $\begin{array}{l}\text { Een significant verband was zichtbaar tussen de inname van } \\
\text { magere en halfvolle zuivelproducten en het risico op diabetes } \\
\text { mellitus type } 2 \text { (RR: } 0,83,95 \% \text { BI: } 0,76 \text { tot } 0,90 \text { ). Er zijn } \\
\text { aanwijzingen voor een niet-lineair verband tussen } \\
\text { zuivelproducten met een laag vetgehalte en het risico op } \\
\text { diabetes type 2, zonder verdere risicoreductie bij het gebruik } \\
\text { vanaf } 300 \text { tot } 400 \text { gram per dag. }\end{array}$ \\
\hline Chen et al, 2014 & $\begin{array}{l}\text { Meta-analyse van cohorts } \\
\text { PRISMA design }\end{array}$ & $\begin{array}{l}3 \text { cohorts } \\
194,458 \text { participanten }\end{array}$ & $\begin{array}{l}\text { Hoge vs. lage inname magere } \\
\text { en halfvolle melk }\end{array}$ & $\overline{-}$ & $\begin{array}{l}\text { Er zijn wat aanwijzingen voor een verband tussen de inname } \\
\text { van volle melkproducten en het risico op diabetes type } 2 \text { (RR: } \\
1,08,95 \% \text { BI: } 1,02 \text { tot } 1,14) \text {. Echter, de auteurs noemen dat } \\
\text { mogelijk reverse causation de bevindingen kan vertekenen: } \\
\text { deelnemers die gedurende de follow-up een hoog } \\
\text { cholesterolgehalte of hoge bloeddruk hun voedingspatroon } \\
\text { hebben veranderd en juist meer halfvolle en magere } \\
\text { melkproducten zijn gaan eten. Wanneer de } \\
\text { voedingsvragenlijsten van deze deelnemers niet werden } \\
\text { meegenomen, werd het RR minder groot (RR: } 1,03,95 \% \text { BI: } \\
0,99 \text { tot 1,07). }\end{array}$ \\
\hline Gao et al, 2013 & $\begin{array}{l}\text { Meta-analyse van cohorts } \\
\text { PRISMA design }\end{array}$ & $\begin{array}{l}3 \text { cohorts } \\
84,019 \text { participanten }\end{array}$ & $\begin{array}{l}\text { Hoge vs. lage inname magere } \\
\text { en halfvolle melk }\end{array}$ & Heterogeniteit: $40 \%$ & $\begin{array}{l}\text { Er zijn wat aanwijzingen voor een significant verband tussen de } \\
\text { inname van volle melkproducten en het risico op diabetes type } \\
2 \text { (RR: } 0,82,95 \% \mathrm{Bl}: 0,69 \text { tot } 0,97) \text {. Er is ook een potentiele niet- } \\
\text { lineaire associatie zichtbaar: een inname van } 300 \mathrm{~g} \text { magere } \\
\text { zuivelproducten kan het risico op diabetes mellitus type } 2 \text { met }\end{array}$ \\
\hline
\end{tabular}


$15 \%$ verlagen. Een hogere intake lijkt niet veel meer positief effect te hebben op het risico van diabetes type 2.

\begin{tabular}{llll}
\hline Aune et al, 2013 & Meta-analyse van cohorts & $\begin{array}{l}3 \text { cohorts } \\
84,019 \text { participanten }\end{array}$ & $\begin{array}{l}\text { Hoge vs. lage inname magere } \\
\text { en halfvolle melk }\end{array}$
\end{tabular}

$R R$ : relative risk = risicoschattin; $B I=$ betrouwbaarheidsinterval . 
Tabel 4d: Systematische reviews en meta-analyses RGV gefermenteerde zuivel in relatie met nuchter bloedsuikergehalte en/of risico op T2DM

\begin{tabular}{|c|c|c|c|c|c|}
\hline Referentie & Studie design & Aantal studies en deelnemers & Blootstelling & Bijzonderheden & Effect van interventie(s) ten opzichte van controle(s) \\
\hline Gao et al, 2013 & $\begin{array}{l}\text { Meta-analyse van cohorts } \\
\text { PRISMA design }\end{array}$ & $\begin{array}{l}3 \text { cohorts } \\
33,893 \text { participanten }\end{array}$ & $\begin{array}{l}\text { Totaal gefermenteerde } \\
\text { zuivelproducten }\end{array}$ & - & $\begin{array}{l}\text { Er zijn geen aanwijzingen aanwezig voor een significant verband } \\
\text { tussen de inname van totaal gefermenteerde zuivelproducten } \\
\text { en het risico op diabetes mellitus type } 2 \text { (RR: } 0,94,95 \% \text { BI: } 0,75 \\
\text { tot } 1,18 \text { ). }\end{array}$ \\
\hline Chen et al, 2014 & $\begin{array}{l}\text { Meta-analyse van cohorts } \\
\text { PRISMA design }\end{array}$ & $\begin{array}{l}9 \text { cohorts } \\
408,096 \text { participanten }\end{array}$ & Hoge vs. lage inname yoghurt & Heterogeniteit: $63,2 \%$ & $\begin{array}{l}\text { Er was een significant verband zichtbaar tussen de inname van } \\
\text { yoghurt en het risico op diabetes mellitus type } 2 \text { (RR: } 0,82,95 \% \\
\text { BI: } 0,70 \text { tot } 0,96 \text { ). In de meta-analyse wordt niet aangegeven } \\
\text { wat de spreiding is m.b.t. de yoghurt inname. In andere meta- } \\
\text { analyses lopen groepen met een hoge inname van yoghurt van } \\
60-115 \text { gram per dag. }\end{array}$ \\
\hline Chen et al, 2014 & $\begin{array}{l}\text { Meta-analyse van cohorts } \\
\text { PRISMA design }\end{array}$ & $\begin{array}{l}3 \text { cohorts } \\
194,458 \text { participanten }\end{array}$ & Hoge vs. lage inname kaas & - & $\begin{array}{l}\text { De gepoolde analyse levert aanwijzingen voor een verband } \\
\text { tussen een hoog gebruik van kaas en een hoger risico op } \\
\text { diabetes mellitus type } 2 \text {, dit is niet significant in de hoog-laag } \\
\text { analyse (RR: } 1,08,95 \% \text { Bl: } 0,96 \text { tot } 1,20 \text { ) en wel significant in de } \\
\text { dosis respons analyse (per portie kaas) (RR: } 1,07,95 \% \text { BI: } 1,03 \\
\text { tot } 1,11 \text { ). }\end{array}$ \\
\hline Aune et al, 2013 & Meta-analyse van cohorts & $\begin{array}{l}8 \text { cohorts } \\
242,960 \text { participanten }\end{array}$ & Hoge vs. lage inname kaas & Heterogeniteit: $0 \%$ & $\begin{array}{l}\text { Er was een significant verband zichtbaar tussen de inname van } \\
\text { kaas en het risico op diabetes type } 2 \text { (RR: } 0,91,95 \% \text { BI: } 0,84 \text { tot } \\
0,98 \text { ). In deze meta-analyse hangt dus een hoog gebruik van } \\
\text { kaas samen met een } 9 \% \text { lager risico op diabetes mellitus type } 2 \text {. }\end{array}$ \\
\hline
\end{tabular}

RR: relative risk $=$ risicoschatting; $B I=$ betrouwbaarheidsinterval. 


\section{Tabel 5: Samenvattingstabel: Conclusies zuivelinname in relatie met parameter gerelateerd aan metabool syndroom}

\begin{tabular}{|c|c|c|c|c|c|}
\hline WC or BW & TG & HDL-C & LDL-C & BP* & FG or risk of development T2DM \\
\hline $\begin{array}{l}\text { - } \\
\text { - op basis van Benatar et al, } 2013 \\
\text { - op basis van Abargouei et al, } 2012 \\
\text { - op basis van Chen et al, } 2012 \\
\text { Meta-analyses leveren aanwijzingen } \\
\text { dat onder ad libitum omstandigheden } \\
\text { het gebruik van drie porties totale } \\
\text { zuivel gedurende een half jaar, en } \\
\text { vooral het advies om extra te } \\
\text { gebruiken, het lichaamsgewicht } \\
\text { verhoogt met } 0,5 \text { kilogram bij } \\
\text { volwassenen. Met het oog op de } \\
\text { verklaarde heterogeniteit in de meta- } \\
\text { analyse van Benatar et al, beoordeelt } \\
\text { de commissie de bewijskracht als groot. } \\
\text { De auteurs veronderstellen dat het } \\
\text { advies van extra zuivel naast de } \\
\text { gebruikelijke voedingsinname een } \\
\text { mogelijke verklaring kan zijn voor de } \\
\text { gewichtstoename. }\end{array}$ & - & - & $\begin{array}{l}? \\
\text { - op basis van Benatar et al, } \\
2013 \\
\text { Er is te weinig onderzoek om } \\
\text { een uitspraak te doen over het } \\
\text { effect van volle ten opzichte } \\
\text { van halfvolle en magere zuivel } \\
\text { op het LDL-cholesterol. } \\
\text { Het effect van totale zuivel op } \\
\text { het LDL-cholesterol is } \\
\text { onwaarschijnlijk. } \\
+ \text { (Yoghurt) } \\
\text { - op basis van Agerholm-Larsen } \\
\text { et al, } 2000 \text { (MA) } \\
\text { Het effect van specifiek- } \\
\text { gefermenteerde yoghurt ten } \\
\text { opzichte van aangezuurde } \\
\text { yoghurt op LDL-cholesterol is } \\
\text { niet eenduidig. }\end{array}$ & $\begin{array}{l}\text { ? } \\
\text { - op basis van Benatar et al, } 2013 \\
\text { De commissie concludeert dat een } \\
\text { effect van het gebruik van totale } \\
\text { zuivel op de systolische bloeddruk } \\
\text { onwaarschijnlijk is. } \\
\text { +(gefermenteerde } \\
\text { zuivelproducten) } \\
\text { - op basis van Dong et al, } 2013 \\
\text { De commissie concludeert dat het } \\
\text { gebruik van gefermenteerde ten } \\
\text { opzichte van ongefermenteerde } \\
\text { zuivelproducten de systolische } \\
\text { bloeddruk verlaagt. Omdat in de } \\
\text { meta-analyse onderzoeken naar } \\
\text { uiteenlopende gefermenteerde } \\
\text { producten zijn samengevat en de } \\
\text { controlebehandelingen voor een } \\
\text { deel onduidelijk zijn, beoordeelt de } \\
\text { commissie de bewijskracht als } \\
\text { gering. }\end{array}$ & $\begin{array}{l}\text { 0 } \\
\text { - op basis van Chen et al, } 2014 \\
\text { - op basis van Aune et al, } 2013 \\
\text { - op basis van Gao et al, } 2013 \\
\text { Op grond van de meta-analyse concludeert de commissie dat } \\
\text { een verband tussen het gebruik van totale en volle zuivel en het } \\
\text { risico op diabetes mellitus onwaarschijnlijk is. } \\
\text { 0 } \\
\text { - op basis van Tong et al, } 2011 \\
\text { Een verband tussen het gebruik van volle zuivel en het risico op } \\
\text { diabetes mellitus type } 2 \text { is onwaarschijnlijk. } \\
\text { ? } \\
\text { - op basis van Chen et al, } 2014 \\
\text { - op basis van Aune et al, } 2013 \\
\text { - op basis van Gao et al, } 2013 \\
\text { Een verband tussen het gebruik van totale melk, volle melk, } \\
\text { halfvolle, magere melk en het risico op diabetes mellitus type } 2 \\
\text { is niet eenduidig. } \\
\text { Het verband tussen het gebruik van gefermenteerde } \\
\text { zuivelproducten en het risico op diabetes mellitus type } 2 \text { is niet } \\
\text { eenduidig. } \\
\text { Het verband tussen het gebruik van kaas en het risico op } \\
\text { diabetes mellitus type } 2 \text { is niet eenduidig. } \\
\text { + (halfvolle en magere zuivelproducten) } \\
\text { - op basis van Aune et al, } 2013 \\
\text { De commissie concludeert dat het gebruik van halfvolle en } \\
\text { magere zuivelproducten samenhangt met een lager risico op }\end{array}$ \\
\hline
\end{tabular}




\begin{tabular}{|l|l|l|l|l|}
\hline & & & & $\begin{array}{l}\text { diabetes mellitus type 2. Omdat de gepoolde analyse de } \\
\text { bevindingen uit de meta-analyse niet bevestigt, beoordeelt de } \\
\text { commissie de bewijskracht als gering. } \\
+ \text { (Yoghurt) } \\
\text { - op basis van Chen et al, 2014 } \\
\text { Het gebruik van } 60 \text { gram of meer yoghurt per dag samenhangt } \\
\text { met ongeveer 15\% lager risico op diabetes mellitus type } 2 \text { ten } \\
\text { opzichte van minder dan 10 gram per dag. Met het oog op de } \\
\text { verklaarde heterogeniteit, beoordeelt de commissie de } \\
\text { bewijkracht als groot. }\end{array}$ \\
\hline
\end{tabular}

* In de richtlijnen goede voeding 2015 wordt er uitgegaan van alleen de systolische bloeddruk. 


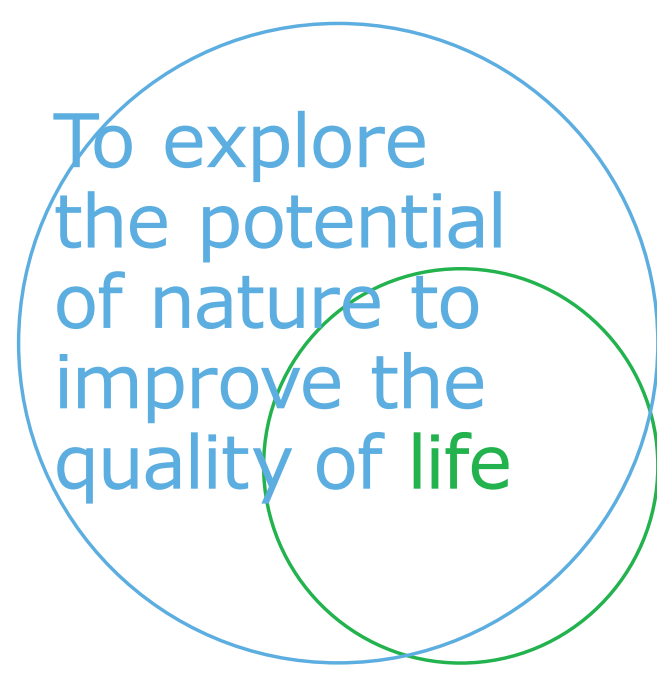

Wageningen Food \& Biobased Research Bornse Weilanden 9

6708 WG Wageningen

The Netherlands

www.wur.eu/wfbr

Einfo.wfbr@wur.nl

Report 2122

Confidential

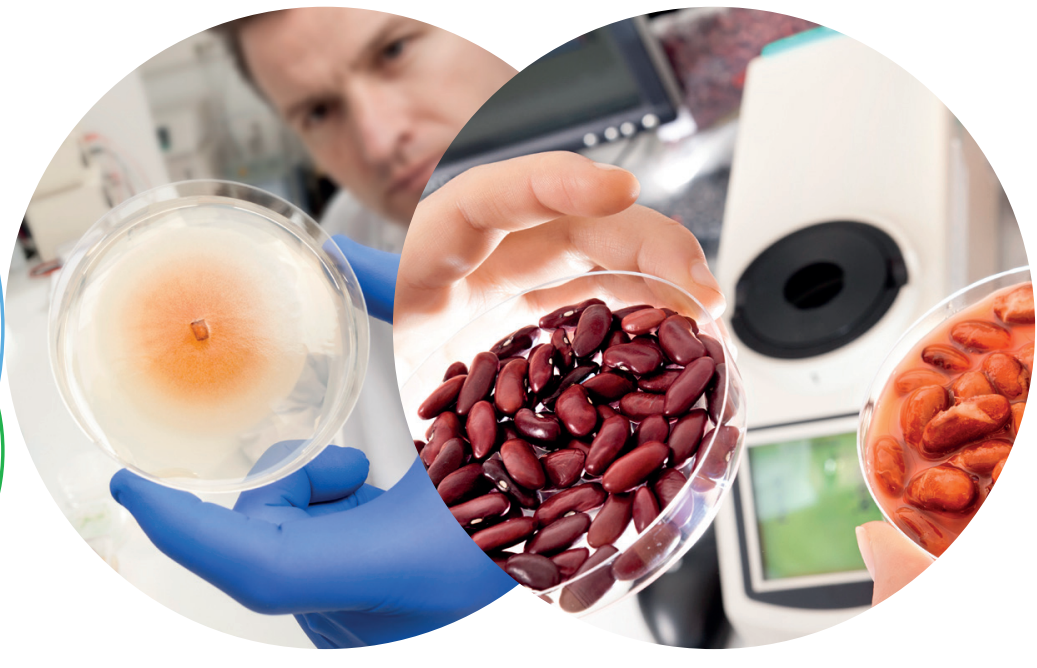

The mission of Wageningen University and Research is "To explore the potential of nature to improve the quality of life". Under the banner Wageningen University \& Research, Wageningen University and the specialised research institutes of the Wageningen Research Foundation have joined forces in contributing to finding solutions to important questions in the domain of healthy food and living environment. With its roughly 30 branches, 6,500 employees (5,500 fte) and 12,500 students, Wageningen University \& Research is one of the leading organisations in its domain. The unique Wageningen approach lies in its integrated approach to issues and the collaboration between different disciplines. 